\title{
Kesesuaian antara Foto Toraks dan Mikroskopis Sputum pada Evaluasi Respons Pengobatan Tuberkulosis Paru setelah Enam Bulan Pengobatan
}

\author{
Ristaniah D. Soetikno, ${ }^{1}$ Derry $^{2}$ \\ ${ }^{1}$ Departemen Radiologi Fakultas Kedokteran Universitas Padjadjaran- \\ Rumah Sakit Dr. Hasan Sadikin, Bandung, ${ }^{2}$ Bagian Radiologi Rumah Sakit Dustira
}

\begin{abstract}
Abstrak
Evaluasi pengobatan penderita tuberkulosis paru meliputi evaluasi klinis, bakteriologis, dan radiologis. Evaluasi bakteriologis bertujuan untuk mendeteksi ada tidaknya konversi sputum yang merupakan indikator keberhasilan pengobatan. Foto toraks merupakan pemeriksaan yang mudah, cepat dengan biaya yang relatif murah, tetapi belum dijadikan indikator keberhasilan pengobatan. Penelitian ini bertujuan mengetahui kesesuaian antara gambaran foto toraks dan sputum mikroskopis pada evaluasi respons pengobatan penderita tuberkulosis paru setelah enam bulan pengobatan. Penelitian dilakukan pada 246 orang penderita baru dengan diagnosis tuberkulosis paru yang telah mendapat pengobatan tuberkulosis selama enam bulan. Data diambil dari penelitian Proverty Related Infection Oriented Research (PRIOR) di Fakultas Kedokteran Universitas Padjadjaran Bandung yang berlangsung dari September 2000 sampai dengan Desember 2005. Pembacaan hasil foto toraks dilakukan oleh dua orang ahli radiologi. Subjek penelitian berusia 15-67 tahun. Hasil pembacaan kedua ahli radiologi menunjukkan kesesuaian antara penilaian foto toraks dan hasil mikroskopis sputum. Nilai kesesuaian hasil pembacaan oleh ahli radiologi I adalah 0,420 (fair) dan ahli radiologi II adalah 0,446 (fair). Simpulan, terdapat kesesuaian antara penilaian foto toraks dan hasil mikroskopis sputum pada evaluasi respons penderita tuberkulosis paru setelah enam bulan pengobatan. Foto toraks dapat dijadikan alternatif evaluasi respons tuberkulosis paru setelah enam bulan pengobatan. [MKB. 2011;43(3):140-5].
\end{abstract}

Kata kunci: Foto toraks, sputum mikroskopis, tuberkulosis paru

\section{Compatibility between Chest Radiograph and Microscopic Sputum Examination at Response Evaluation of Lungs Tuberculosis after Six Months of Therapy}

\begin{abstract}
Evaluation of pulmonary tuberculosis treatment include clinical, bacteriological, and radiological evaluation. Bacteriological evaluation aims to detect sputum conversion as an indicator of treatment success. Chest radiograph is simple, quick and relatively low cost, but it has not been used as an indicator of treatment success. This study aims was to compare the compatibility between chest radiograph and microscopic sputum in patients with lung tuberculosis after sixth months of treatment. The study was conducted on 246 new lung tuberculosis patients that had received treatment for six months. Data was taken from Proverty Related Infection Oriented Research (PRIOR) at Medical Faculty of Padjadjaran University in Bandung that was held from September 2000 to December 2005. Assessment of chest radiographs was performed by two expert radiologists. Age of the subjects were 15-67 years old. The study showed that chest radiograph assessment was compatible with sputum microscopy result. The suitability value between them was 0.420 (fair) by the first radiologist and 0.446 (fair) by the second radiologists. In conclusion, there is compatibility between assessment chest radiograph and microscopic sputum examination at the responses evaluation of the lung tuberculosis patients after six months of therapy. Chest radiograph can be an alternative for response evaluation of lung tuberculosis after six months of therapy. [MKB. 2011;43(3):140-5].
\end{abstract}

Key words: Lungs tuberculosis, microscopic sputum, thorax photo

Korespondesi: Dr. Ristaniah D. Soetikno, dr., Sp.Rad., M.Kes, Departemen Radiologi Fakultas Kedokteran-Rumah Sakit Dr. Hasan Sadikin, jalan Pasteur 38 Bandung, telepon (022) 2034915, e-mail: ristasoetikno@gmail.com 


\section{Pendahuluan}

Tuberkulosis saat ini masih merupakan masalah kesehatan masyarakat di banyak negara terutama di negara berkembang. ${ }^{1,2}$ World Health Organization (WHO) menyatakan bahwa sekitar 1,9 miliar manusia atau sepertiga penduduk dunia ini telah terinfeksi kuman tuberkulosis. Pada dekade ini terjadi 2,9 juta kematian akibat tuberkulosis serta infeksi HIV dan sebagian besar terjadi di negara berkembang. ${ }^{2,3}$

Berdasarkan pada Pedoman Penatalaksanaan Tuberkulosis Paru, maka diagnosis tuberkulosis paru ditegakkan berdasarkan gejala/pemeriksaan klinis, radiologis, dan laboratorium. ${ }^{3}$ Sesuai rekomendasi WHO, maka diagnosis tuberkulosis paru berdasarkan pemeriksaan sputum secara mikroskopis, oleh karena hal ini merupakan pemeriksaan yang efisien, mudah, murah, dan cukup cepat (dua hari) ${ }^{3-7}$ Mikroskopis sputum ini bersifat spesifik dan cukup sensitif. Pemeriksaan sputum juga bertujuan untuk menilai kemajuan pengobatan dan menentukan tingkat penularan. American Tuberculosis Association menyatakan bahwa diagnosis pasti tuberkulosis paru adalah dengan menemukan kuman Mycobacterium tuberculosis dalam sputum atau jaringan paru secara biakan. ${ }^{6,7}$

Dalam menegakkan diagnosis tuberkulosis paru, gambaran radiologis tidak selalu khas dan sangat bervariasi, tetapi foto toraks merupakan pemeriksaan penunjang pertama yang membantu untuk menegakkan diagnosis tuberkulosis paru, memonitor respons pengobatan, dan membantu dalam menghambat penyebaran infeksi. ${ }^{3}$ Selain itu, foto toraks merupakan cara yang praktis, cepat, dan mudah untuk menemukan lesi tuberkulosis. Foto toraks juga dapat memberikan gambaran radiologis tuberkulosis paru pada tuberkulosis paru basil tahan asam (BTA) positif ataupun BTA negatif, sehingga foto toraks dapat menyokong klinisi dalam menegakkan diagnosis tuberkulosis paru. ${ }^{4,6,7}$

Pengobatan tuberkulosis diberikan dalam dua tahapan, yaitu tahap intensif dengan lama pengobatan dua bulan dan tahap lanjutan dengan lama pengobatan selama 6 bulan., ${ }^{27-11}$ Evaluasi pengobatan pada penderita tuberkulosis paru meliputi evaluasi klinis, bakteriologis, radiologis, efek samping obat, penanganan efek samping obat, serta keteraturan berobat. Evaluasi klinis dilakukan setiap dua minggu pada satu bulan pertama pengobatan, selanjutnya setiap satu bulan. Evaluasi bakteriologik merupakan pemeriksaan yang penting dalam menilai respons pengobatan dan bertujuan untuk mendeteksi ada tidaknya konversi sputum. Adanya konversi sputum bulan keenam merupakan indikator keberhasilan pengobatan. ${ }^{2,11-15}$ Singla dkk. ${ }^{13}$ mengadakan penelitian tentang konversi sputum dan menunjukkan konversi sputum terjadi lebih dari $80 \%$ pada bulan kedua pengobatan. Evaluasi radiologis kurang berperan terhadap evaluasi pengobatan, karena perubahan gambaran foto toraks terjadi lebih lambat dibandingkan dengan perubahan bakteriologis dan bahkan dalam tiga bulan pengobatan dapat terjadi perburukan gambaran radiologis. Perubahan gambaran radiologis memerlukan waktu antara enam bulan sampai dua tahun.

Pada akhir bulan pengobatan diharapkan penderita sudah dapat dinyatakan sembuh secara klinis, bakteriologis, dan radiologis. Penderita tuberkulosis yang telah dinyatakan sembuh tetap dievaluasi minimal dua tahun setelah sembuh untuk mengetahui adanya kekambuhan. Pemeriksaan untuk evaluasi penderita yang telah sembuh adalah pemeriksaan mikroskopis sputum dan pemeriksaan radiologis. ${ }^{4-14}$

Tujuan penelitian adalah untuk mengetahui kesesuaian gambaran antara foto toraks dan mikroskopis sputum pada evaluasi respons pengobatan tuberkulosis paru setelah enam bulan pengobatan dan apakah pemeriksaan foto toraks dapat dipakai sebagai alternatif evaluasi respons pengobatan penderita tuberkulosis paru setelah enam bulan pengobatan.

\section{Metode}

Subjek penelitian yang dipilih adalah semua penderita dengan diagnosis tuberkulosis paru berdasarkan pemeriksaan mikroskopis sputum dan gambaran radiologis yang telah mendapat pengobatan tuberkulosis selama enam bulan. Subjek berusia $\geq 15$ tahun dan baru pertama mendapat pengobatan tuberkulosis. Penelitian dilakukan di Poliklinik Subbagian Pulmonologi Departemen Ilmu Penyakit Dalam Rumah Sakit Dr. Hasan Sadikin Bandung, Pemberantasan Penyakit Tuberkulosis Indonesia (PPTI) DKI Jakarta, dan Balai Pemberantasan Penyakit ParuParu (BP4) Bandung. Penelitian dilakukan dari September 2000 sampai dengan Desember 2005. Subjek yang memiliki penyakit penyerta seperti diabetes melitus, gagal ginjal, artritis rematoid, dan lupus eritematosus sistemik, tidak disertakan dalam penelitian. Data diambil dari penelitian Proverty Related Infection Oriented Research (PRIOR) Fakultas Kedokteran Universitas Padjadjaran Bandung.

Rancangan penelitian ini adalah observational secara cross sectional. Pada penelitian ini dilakukan evaluasi sputum dan foto toraks setelah enam bulan pengobatan. Penderita dengan 
diagnosis tuberkulosis paru mikroskopis sputum positif yang telah memenuhi kriteria inklusi dan tidak memenuhi kriteria eksklusi dikelompokkan sebagai eligible participant hingga mencapai ukuran sampel yang ditentukan. Ukuran sampel sebesar 246 subjek ditentukan berdasarkan akurasi yang dikehendaki 0,80 dan bond of error (precision) 0,05. Pemilihan subjek penelitian dilakukan secara consecutive admissions (urutan datang penderita).

Data pemeriksaan sputum dikelompokkan menjadi 4 kategori berdasarkan modifikasi skala International Union Against Tuberculosis and Lung Disease (IUATLD). Negatif yang berarti tidak ditemukan basil tahan asam (BTA) dalam 100 lapang pandang. Positif 1 yang berarti ditemukan 1-99 BTA/100 lapang pandang. Positif 2 yang berarti ditemukan 1-10 BTA/1 lapang pandang (minimal dibaca 50 lapang pandang). Positif 3 yang berarti ditemukan >10 BTA/1 lapang pandang (minimal dibaca 20 lapang pandang).

Hasil pembacaan foto toraks juga dikelompokkan menjadi 4 kategori berdasarkan American Tuberculosis Association. Negatif yang berarti tidak ditemukan kelainan pada foto toraks atau adanya gambaran tuberkulosis paru tenang yang ditandai dengan gambaran fibrosis, kalsifikasi, dan atau penebalan pleura. Positif 1 atau minimal lesion yang berarti bercak dapat mengenai satu atau kedua paru, tetapi luas bercak tidak melebihi daerah yang dibatasi oleh garis tengah, apeks, dan iga kedua depan atau di atas second chondrosternal junction dan vertebra torakal keempat atau kelima. Tidak ditemukan adanya kavitas. Positif 2 atau moderately advanced lesion yang berarti bercak dapat mengenai satu atau kedua paru, tetapi tidak melebihi luas satu paru. Bila ditemukan kavitas, diameternya tidak melebihi $4 \mathrm{~cm}$. Kalau terdapat konsolidasi yang homogen, luasnya tidak melebihi luas satu lobus paru atau sepertiga volume satu paru. Positif 3 atau far advanced lesion yang berarti luas bercak lebih dari luas bercak pada positif 2 atau bila ada kavitas yang berdiameter lebih dari $4 \mathrm{~cm}$.

Data yang terkumpul disusun dalam tabel dan selanjutnya dilakukan analisis data menggunakan parameter coefficient of agreement Kappa (K) dengan nilai $\mathrm{K} \geq 0,75$ berarti excellent, nilai $\mathrm{K}$ antara 0,40 dan 0,75 adalah fair, dan nilai $\mathrm{K}<0,40$ adalah poor.

Pada penelitian ini nilai Kappa yang pakai untuk kesesuaian antara mikroskopis sputum dan foto toraks adalah nilai Kappa $\geq 0,40<<0,75$ (fair), artinya peneliti akan menyarankan foto toraks sebagai alternatif pemeriksaan pada evaluasi setelah enam bulan terapi penderita tuberkulosis paru apabila hasil nilai Kappa adalah fair.

\section{Hasil}

Pada penelitian ini dari ukuran sampel sebanyak 246 orang, jumlah kasus terbanyak didapatkan pada kelompok usia 20-29 tahun, yakni 115 orang $(46,8 \%)$, sedangkan jumlah kasus paling sedikit didapatkan pada kelompok usia di atas 60 tahun $(1,2 \%)$. Dari 246 subjek penelitian yang masuk kriteria inklusi, didapat usia rerata adalah 30,36 tahun.

Data hasil pemeriksaan mikroskopis sputum dan foto toraks yang diperoleh dapat dilihat pada Tabel 2, sedangkan analisis data dapat dilihat

Tabel 1 Distribusi Subjek Penelitian Menurut Kelompok Usia

\begin{tabular}{ccc}
\hline Kelompok Usia (tahun) & Jumlah (n = 246) & \% \\
\hline$<19$ & 23 & 9,3 \\
$20-29$ & 115 & 46,8 \\
$30-39$ & 65 & 26,4 \\
$40-49$ & 27 & 11,0 \\
$50-59$ & 13 & 5,3 \\
$>60$ & 3 & 1,2 \\
Total & 246 & 100,0 \\
Rerata (tahun) & 30,36 & \\
Median (tahun) & 27,50 & \\
Simpang baku (tahun) & 10,20 & \\
Minimum (tahun) & 15 & \\
Maksimum (tahun) & 67 & \\
\hline
\end{tabular}


Tabel 2 Pembacaan Foto Toraks oleh Ahli Radiologi I dan Ahli Radiologi II berdasarkan Pemeriksaan Mikroskopis Sputum

\begin{tabular}{|c|c|c|c|c|c|c|c|c|c|c|}
\hline \multirow{3}{*}{ Sputum } & \multicolumn{10}{|c|}{ Foto Toraks } \\
\hline & \multicolumn{2}{|c|}{ Negatif } & \multicolumn{2}{|c|}{ Positif 1} & \multicolumn{2}{|c|}{ Positif 2} & \multicolumn{2}{|c|}{ Positif 3} & \multicolumn{2}{|c|}{ Total } \\
\hline & I & II & I & II & $\mathbf{I}$ & II & I & II & I & II \\
\hline Negatif & 221 & 226 & 15 & 9 & 3 & 4 & 0 & 0 & 239 & 239 \\
\hline Positif 1 & 0 & 1 & 3 & 2 & 0 & 0 & 0 & 0 & 3 & 3 \\
\hline Positif 2 & 0 & 0 & 0 & 0 & 2 & 2 & 0 & 0 & 2 & 2 \\
\hline Positif 3 & 0 & 0 & 0 & 0 & 0 & 0 & 2 & 2 & 2 & 2 \\
\hline Total & 221 & 227 & 18 & 11 & 5 & 6 & 2 & 2 & 246 & 246 \\
\hline
\end{tabular}

I : Ahli Radiologi I

II : Ahli Radiologi II

pada Tabel 3 .

Nilai Kappa hasil pembacaan oleh ahli radiologi I secara keseluruhan adalah fair. Untuk foto toraks dan sputum yang hasil pemeriksaannya menunjukkan telah negatif, nilai Kappa adalah poor, sedangkan untuk nilai Kappa dari hasil pembacaan yang menunjukkan positif 1 , positif 2, dan positif 3 adalah excellent (Tabel 3).

Nilai Kappa hasil pembacaan oleh ahli radiologi II secara keseluruhan adalah fair. Untuk foto toraks dan mikroskopis sputum yang hasil pemeriksaannya menunjukkan telah negatif, nilai Kappa adalah poor, sedangkan untuk nilai Kappa dari hasil pembacaan yang menunjukkan positif 1 adalah fair. Untuk nilai Kappa dari hasil pembacaan yang menunjukkan positif 2 dan positif 3 adalah excellent (Tabel 3 ).

\section{Pembahasan}

Pada penelitian ini subjek penelitian berusia 15-67 tahun dengan jumlah kasus terbanyak didapatkan pada kelompok usia 20-29 tahun, hal ini sesuai dengan laporan WHO tahun 2002 yang menyatakan bahwa usia terbanyak penderita tuberkulosis adalah 15-49 tahun. Laporan yang sama juga didapatkan di daerah Jawa Barat pada tahun 2003, distribusi kasus tuberkulosis paru berdasarkan kelompok usia terbanyak pada usia 15-54 tahun, sedangkan data dari Rumah Sakit Dr. Hasan Sadikin Bandung penderita yang dirawat pada tahun 1995/1996 terbanyak pada usia 15-24 tahun.

Distribusi penderita berdasarkan jenis kelamin pada penelitian ini terbanyak pada perempuan dibandingkan dengan laki-laki. Keadaan ini berbeda dari laporan WHO tahun 2002, hasil penelitian Rao dan Sadiq ${ }^{12}$ tahun 2000, laporan dari provinsi Jawa Barat dan data dari Rumah Sakit Dr. Hasan Sadikin Bandung tahun 1995/1996, yang semuanya mendapatkan penderita laki-laki sedikit lebih banyak dibandingkan dengan perempuan. Laporan WHO menyatakan tidak ada perbedaan kemungkinan timbulnya kasus tuberkulosis paru antara laki-laki dan perempuan, diperkirakan jumlah penderita laki-laki sama banyak dengan perempuan. Dengan demikian, jumlah kasus yang selama ini dilaporkan bahwa perempuan lebih sedikit

Tabel 3 Kesesuaian Pemeriksaan Mikroskopis Sputum dan Foto Toraks yang Dibaca oleh Ahli Radiologi I dan Ahli Radiologi II

\begin{tabular}{ccccccccccc}
\hline \multirow{2}{*}{ Kategori } & \multicolumn{2}{c}{ Ḱi } & \multicolumn{2}{c}{ Se ('́) } & \multicolumn{2}{c}{ Z } & \multicolumn{2}{c}{ P } & \multicolumn{2}{c}{ Keterangan } \\
\cline { 2 - 11 } & I & II & I & II & I & II & I & II & I & II \\
\hline Keseluruhan & 0,42 & 0,45 & 0,11 & 0,12 & 11,16 & 11,11 & 0,00 & 0,00 & Fair & Fair \\
Negatif & 0,26 & 0,30 & 0,03 & 0,04 & 7,98 & 7,84 & 0,00 & 0,00 & Poor & Poor \\
Positif 1 & 1,00 & 0,65 & 0,16 & 0,12 & 6,20 & 5,24 & 0,00 & 0,00 & Excellent & Fair \\
Positif 2 & 1,00 & 1,00 & 0,20 & 0,11 & 5,03 & 8,98 & 0,00 & 0,00 & Excellent & Excellent \\
Positif 3 & 1,00 & 1,00 & 0,06 & 0,06 & 15,68 & 15,68 & 0,00 & 0,00 & Excellent & Excellent \\
\hline
\end{tabular}

I : Ahli Radiologi I

II : Ahli Radiologi II 
kasusnya disebabkan kemungkinan karena kurang terdiagnosis. Beberapa alasan perempuan tidak terdiagnosis sebagaimana mestinya, di antaranya yaitu perempuan merasa tidak ada waktu karena kesibukannya mengurus keluarga, masalah biaya dan transportasi, tingkat pendidikan yang relatif masih rendah, dan faktor sosiobudaya yang menghambat perempuan untuk kontak dengan petugas kesehatan laki-laki. ${ }^{3,4}$ Pada penelitian ini jumlah penderita perempuan lebih banyak, ini kemungkinan disebabkan beberapa alasan di atas tidak menjadi masalah lagi seperti masalah transportasi dan tingkat pendidikan perempuan yang semakin tinggi saat ini.

Pada penelitian ini nilai Kappa hasil pembacaan kedua ahli radiologi menunjukkan kesesuaian antara hasil pemeriksaan mikroskopis sputum dan penilaian foto toraks. Nilai Kappa secara keseluruhan adalah fair yang artinya foto toraks dapat dijadikan alternatif pemeriksaan pada evaluasi respons pengobatan penderita tuberkulosis paru setelah enam bulan pengobatan. Nilai Kappa secara klasifikasi (negatif, positif 1, positif 2, dan positif 3) dari ahli radiologi I dan ahli radiologi II hasilnya bervariasi. Nilai Kappa dari kedua ahli radiologi untuk hasil negatif adalah poor, artinya pada hasil sputum yang telah negatif (239 orang) ada foto toraks yang hasilnya masih menunjukkan positif (ahli radiologi I sebanyak 18 orang dan ahli radiologi II sebanyak 13 orang). Hal ini menunjukkan perubahan pada foto toraks tidak secepat perubahan mikroskopis sputum dan keadaan ini sesuai dengan pendapat yang menyatakan perubahan foto toraks terjadi lebih lambat dibandingkan dengan perubahan bakteriologis dan perubahan gambaran radiologis memerlukan waktu antara 6 bulan sampai 2 tahun. ${ }^{14}$ Nilai Kappa untuk hasil positif 1 sampai positif 3 menunjukkan hasil fair dan excellent pada kedua ahli radiologi, artinya hasil positif pada mikroskopis sputum ditunjukkan juga pada foto toraks yang menunjukkan hasil positif (aktif). Dengan demikian, kekeliruan dapat saja terjadi saat menilai foto toraks pada mikroskopis sputum negatif dan kekeliruan tidak terjadi saat menilai foto toraks pada mikroskopis sputum positif.

Kesesuaian antara hasil pembacaan foto toraks ahli radiologi I dan ahli radiologi II, nilai Kappa secara keseluruhan adalah fair, artinya tidak ada perbedaan antara kedua ahli radiologi secara keseluruhan dalam menilai foto toraks. Nilai Kappa secara klasifikasi hanya pada positif 1 (minimal) yang kesesuaiannya poor, sedangkan pada klasifikasi lainnya (tidak aktif, moderate, dan advance) hasilnya fair dan excellent, ini artinya ada perbedaan pembacaan pada hasil positif satu (minimal) dan hasil ini kemungkinan dipengaruhi oleh subjektivitas pada saat pembacaan.

Penelitian lebih lanjut diperlukan untuk mengetahui pada bulan ke berapa perubahan foto toraks tersebut terjadi dan faktor-faktor apa saja yang mempengaruhi ketidaksesuaian ini.

Kesimpulan penelitian ini adalah terdapat kesesuaian antara penilaian foto toraks dan hasil mikroskopis sputum pada evaluasi respons pengobatan penderita tuberkulosis paru setelah enam bulan pengobatan.

\section{Daftar Pustaka}

1. Frieden RT, Sterling TR, Munsiff SS, Watt CJ, Dye C. Tuberculosis. Lancet. 2003;362:88799.

2. Departemen Kesehatan RI. Pedoman nasional penanggulangan tuberkulosis. Jakarta: Depkes RI; 2005.

3. Mfinanga GS, Ngadaya E, Mtandu R, Mutayoba B, Basra D, Kimaro G, dkk. The quality of sputum smear microscopy diagnosis of pulmonary tuberculosis in Dar es Salaam, Tanzania. Tanzania Health Research Bull. 2007;9(3):164-8.

4. Ben-Salma W, Ben-Kahla I, Marzouk M, Farjeni A, Ghezal S, Ben-Said M, dkk. Rapid detection of Mycobacterium tuberculosis in sputum by patho-TB kit in comparison with direct microscopy and culture. Diagnostic Microbiol Infect Dis. 2009;65(3):232-5.

5. Anti Tuberculosis Drug Resistant in the World, Report no. 2: prevalence and trend. The WHO/IUATLD Global Project on Anti Tuberculosis Resistant Surveillance. Geneva: CDC-WHO; 2000.

6. Krunner A, Hoffner SE, Sillastu H, Danilovits N, Levina K, Svenson SB, dkk. Spread of drug resistant pulmonary tuberculosis in Estonia. J Clin Microbiol. 2001;39:3339-45.

7. Srikanth P, Kamesh S, Daley P. Bleach optimization of sputum smear microscopy for pulmonary tuberculosis. Indian J Tuberc. 2009;56(4):178-84.

8. Arslan S, Ozdemir L, Demirel Y, Akkurt I. The validity of the diagnostic methods in predicting pulmonary tuberculosis. J Microbiol Research. 2010;4(8):613-7.

9. Aditama TY. Tuberkulosis: diagnosis, terapi, dan masalahnya. Edisi ke-4. Jakarta: Yayasan Penerbitan Ikatan Dokter Indonesia; 2002.

10. Anh DD, Borgdoff MW, Lan NTN, Gorkim TV, Kremer K. Beijing genotype emerging in Vietnam. Emerg Infect Dis. 2000;6:302-5.

11. Drobniewski F, Balabanova Y, Nikolayevsky V, Ruddy M, Kuznetzov S, Zakharova S, dkk. Drug-resistant tuberculosis, clinical 
virulence, and the dominance of the Beijing strain family in Russia. JAMA. 2005;293(22):2726-31.

12. Rao NA, Sadiq MA. Recent trend in the radiological presentation of pulmonary tuberculosis in Pakistani adults. JPMA. 2002;52:501.

13. Singla R, Singla N, Sarin R, Arora VK. Influence of pre-treatment bacillary load on treatment outcome of pulmonary tuberculosis patient receiving DOTS under revised national tuberculosis control programme. Chest Dis Sci. 2005;47:19-23.

14. Deun A, Salim AH, Cooreman E. Optimal tuberculosis case detection by direct sputum smear microscopy: how much better is more? Int J Tuberc Lung Dis. 2002;6(3):222-30.

15. Fitzgerald M, Hotaling JE, O'Donnell D, Parsons LM, Salfinger M, Somoskovi A. Lessons from a proficiency testing event for acid-fast microscopy. Chest. 2001;120:2507. 